(C) 1984. The Genetical Society of Great Britain

\title{
ASSORTATIVE MATING IN PHLOX
}

\author{
DONALD A. LEVIN AND LEE WATKINS \\ Department of Botany, University of Texas at Austin, Austin, Texas 78712, USA
}

Received 8.iii.84

\section{SUMMARY}

\begin{abstract}
Experimental populations of $P$. drummondii were established in which pinkflowered and red-flowered variants were distributed in a chequerboard design. The mating patterns therein were estimated from the percentage hybrid progeny. Moderate positive assortative mating occurred when the variants were established at the same height. When stature differentials were introduced, the level of assortative mating increased. Thus pollinators of $P$. drummondii forage in an assortative manner with regard to flower colour and plant stature. The distribution of pollinators on the two phloxes indicated that the pink was not preferred over the red.
\end{abstract}

\section{INTRODUCTION}

Mating systems and the selective forces that have moulded them have been prime subjects of evolutionary thought for over a century. Systems of mating determine the pattern in which gametes are brought together, and thus exert primary control on the relatedness of gametes being joined during fertilisation, the genetic structure of zygote populations, the spatial organisation of variation and levels of gene pool homogenisation. Plant evolutionists have sought to characterise the mating system from pollen and seed dispersal patterns (Levin and Kerster, 1974) and from genotype distributions within and among families (Clegg, 1980). These approaches provide information on the potential for or the actual level of inbreeding within populations. Other systems of mating also may have a substantial impact on the genetic structure of populations, yet have received little attention. Positive assortative mating is the most important in this respect and the most likely deviation from random mating other than inbreeding.

There is considerable potential for assortative mating based upon polymorphic reproductive characteristics in animal-pollinated plant populations. Pollinators such as bees, lepidopterans and hummingbirds can discriminate between colours, odours, corolla sizes and corolla configurations (Faegri and van der Pijl, 1979; Waddington, 1983; Waser, 1983), and such pollinators often remain constant to a single food image in spite of the presence of suitable alternative images (Grant, 1949, 1963; Levin, 1978a). Discontinuous variation in flower colour is known in Linanthus parryae (Epling, Lewis and Ball, 1960), Encelia farnosa (Kyhos, 1971), Leavenworthia crassa (Lloyd, 1969), Lupinus nanus (Harding, 1970), Delphinium nelsonii (Waser and Price, 1981), Circium palustre (Mogford, 1974), Raphanus raphanistrum (Kay, 1976), and Aquilegia caerulea (Miller, 1981). Polymorphisms also are known for floral scent in Gilia species (Grant, 1949), Polemonium viscosum (Galen and Kevan, 1980), and Medicago sativa (Waller et al., 1974), stature in Potentilla erecta (Watson, 1969), flowering time in Nicotiana rustica (Breese, 1956) and Epacris impressa (Stace and 
Fripp, 1977), and for floral form in Dactylorchis fuchsii (Heslop-Harrison, 1958).

In this paper, we describe assortative mating in response to alternative corolla colours and stature differentials in Phlox drummondii Hook. Phlox drummondii is pollinated by a variety of lepidopterans (Battus philenor, Papilio spp., skippers and hawkmoths) (Levin, 1972, 1975). The species is a self-incompatible, spring-flowering annual endemic to the prairies of central Texas. It is composed of pink- and red-flowered population systems which hybridise along zones of secondary contact. Populations in these zones contain pink-flowered and red-flowered plants.

\section{MAterials AND METHOdS}

Experiments on the mating pattern in $P$. drummondii were conducted at the Brackenridge Field Laboratory of the University of Texas. Twentyfour plants each of a red-flowered and a pink-flowered variant were placed eighteen inches apart in a chequerboaid pattern in garden plots cleared of other vegetation. Each plot was arranged into one of three height treatments. In the first two treatments, the two phloxes were displaced vertically eight and sixteen inches, respectively, by raising all pink-flowered plants on inverted pots. All plants were placed at the same level in the third treatment, thus serving as a control. Four plots were established for each of the three height treatments, giving a total of twelve plots. A reciprocal experiment with elevated red-flowered plants was attempted after the first, but it is excluded from the analysis because of poor seed production and germination. As a result, this is not a complete factorial design. However, we show that hybridisation is similar for the high and low varieties.

Seeds from each variant within each plot were collected at approximately bi-weekly intervals. Seeds from each plot were then planted, and progeny were scored as pure or hybrid. Hybrids are easily distinguished by their magenta flowers in contrast to the pink or red flowers of the parental types.

Differences in the percentage of hybrid progeny were investigated after arcsine square root transformation by a split-plot analysis of variance with height differential and corolla colour as the main effects.

Pollinator preference for corolla colour in $P$. drummondii was estimated from observations on approximately one hundred pollinations for each height treatment. These were tabulated and tested for equality using a G-test (Sokal and Rohlf, 1981).

The red-flowered variety was grown from seed collected near Bastrop, Bastrop Co., Texas; and the pink-flowered variety was from seed collected near Austin, Travis Co., Texas. The possibility that hybrid production might be limited due to crossing barriers was investigated using dual pollinations and scoring the frequencies of hybrids among the progeny. Approximately equal amounts of pollen of both varieties were mixed together and placed on stigmas of each variety in a greenhouse. Progeny were identified as hybrids on the basis of flower colour.

\section{Results}

Assortative mating is quite evident in our experimental populations. With no height differential between variants, an average of 37 per cent of the progeny were hybrid compared to 50 per cent expected from random 
mating (table 1). A stature differential between the variants increased the level of assortment beyond that due to colour alone. With an eight inch differential, an average of 26 per cent of the progeny were hybrid, while with a sixteen inch differential only 16 per cent of the progeny were hybrid.

TABLE 1

Percentage hybrid progeny in relation to height differential and corolla color in P. drummondii

\begin{tabular}{ccccc}
\hline & & \multicolumn{3}{c}{ Height differential (inches) } \\
\cline { 3 - 5 } Plot & Colour & Zero & Eight & Sixteen \\
\hline 1 & pink & $38 \cdot 0(150)^{*}$ & $30 \cdot 8(104)$ & $16 \cdot 1(63)$ \\
1 & red & $36 \cdot 0(86)$ & $13 \cdot 6(107)$ & $21 \cdot 2(67)$ \\
2 & pink & $22.2(18)$ & $24 \cdot 0(75)$ & $10 \cdot 0(45)$ \\
2 & red & $38 \cdot 6(41)$ & $22 \cdot 0(72)$ & $20 \cdot 8(49)$ \\
3 & pink & $43 \cdot 9(106)$ & $27 \cdot 6(81)$ & $13 \cdot 9(61)$ \\
3 & red & $41 \cdot 8(106)$ & $42 \cdot 5(81)$ & $17 \cdot 9(104)$ \\
4 & pink & $32 \cdot 0(110)$ & $28 \cdot 3(158)$ & $13 \cdot 1(85)$ \\
4 & red & $33 \cdot 1(163)$ & $28 \cdot 5(88)$ & $17 \cdot 4(119)$ \\
MEAN & & $36 \cdot 6$ & $26 \cdot 1$ & $16 \cdot 1$ \\
\hline
\end{tabular}

* Sample size.

The complete analysis of variance for the colour-height experiment is shown in table 2 . The main effect height is very highly significant, and thus the null hypothesis of no differences between the height treatments may be rejected. The effect of the height differentials is clearly very powerful.

TABLE 2

The analysis of variance of the data shown in table 1

\begin{tabular}{lcc}
\hline Item & d.f. & MS \\
\hline Heights & 2 & $\begin{array}{c}336 \cdot 8052^{* * *} \\
18 \cdot 5137\end{array}$ \\
Plots, within heights & 9 & $22 \cdot 6010$ \\
\hline Colours & 1 & $17 \cdot 0686$ \\
Colours $\times$ Heights & 2 & $18 \cdot 6650$ \\
Colours $\times$ Plots & 9 & - \\
\hline Total & 23 & $11 \cdot 6439$ \\
\hline Theoretical variance & $\infty$ & \\
\hline
\end{tabular}

$$
* * *=P<0.001 \text {. }
$$

Overall, there is no significant difference in the percentage of hybrid progeny produced by the two variants, indicating a lack of pollinator preference (table 2). Were one variant favoured, it would have a substantially lower proportion of hybrid progeny than the ill-favoured variant, because pollinators would forage primarily among plants of the former, and only occasionally switch to the latter. The interaction of corolla colour and height 
differential shows the degree of assortment at each height level does not differ between the variants. In fact, their responses are highly concordant.

If pollinators were moving from plant to plant in a random fashion when no height differences were present, the percentage hybrid progeny should have been proportional to the ratio of the variants, $1: 1$. A G-test of the frequency of hybrid vs. non-hybrid progeny against the expected $1: 1$ ratio revealed a highly significant overall deviation in both variants $(P<$ 0.001 , table 3 ). This consistently was always in the direction of fewer hybrid progeny, and consistently so as indicated by the lack of a significant heterogeneity $G$. Therefore, positive assortative mating is occurring at a statistically significant level.

TABLE 3

Test for random outcrossing in populations of $\mathrm{P}$. drummondii

\begin{tabular}{|c|c|c|c|c|c|c|}
\hline \multicolumn{7}{|c|}{ Progeny of pink-flowered variants } \\
\hline Plot & Parental & Hybrid & Expected & G & df & \\
\hline One & 92 & 58 & 75 & $7 \cdot 7741$ & 1 & $p<0.01$ \\
\hline Two & 14 & 4 & 9 & $5 \cdot 8839$ & 1 & $p<0.025$ \\
\hline Three & 59 & 47 & 53 & $1 \cdot 3614$ & 1 & \\
\hline Four & 75 & 35 & 55 & $14 \cdot 8843$ & 1 & $p<0.001$ \\
\hline Total & 240 & 144 & 192 & 29.9036 & 4 & $p<0.001$ \\
\hline \multicolumn{2}{|c|}{$\begin{array}{l}\text { Pooled G } \\
\text { Heterogeneity } G\end{array}$} & & & $\begin{array}{r}24 \cdot 2565 \\
5 \cdot 6471\end{array}$ & $\begin{array}{l}1 \\
3\end{array}$ & $\begin{array}{c}p<0.001 \\
\text { ns }\end{array}$ \\
\hline \multicolumn{7}{|c|}{ Progeny of red-flowered variants } \\
\hline Plot & Parental & Hybrid & Expected & G & df & \\
\hline One & 55 & 31 & $43 \cdot 0$ & $6 \cdot 7874$ & 1 & $p<0.01$ \\
\hline Two & 23 & 18 & $20 \cdot 5$ & 0.6113 & 1 & ns \\
\hline Three & 62 & 44 & $53 \cdot 0$ & 3.0715 & 1 & ns \\
\hline Four & 108 & 55 & $81 \cdot 5$ & $17 \cdot 5504$ & 1 & $p<0.001$ \\
\hline Total & 248 & 148 & $198 \cdot 0$ & 28.0206 & 4 & $p<0.001$ \\
\hline \multirow{2}{*}{\multicolumn{2}{|c|}{$\begin{array}{l}\text { Pooled G } \\
\text { Heterogeneity } G\end{array}$}} & & & $25 \cdot 5280$ & 1 & $p<0.001$ \\
\hline & & & & $2 \cdot 4926$ & 3 & ns \\
\hline
\end{tabular}

Observations of pollinators showed that the number of plants pollinated of each variant was similar, even when there was a height differential (table 4). Accordingly, neither flower colour is favoured over the other, nor are tall plants more or less attractive than short ones.

TABLE 4

Number of plants pollinated in P. drummondii plots

\begin{tabular}{lccccccc}
\hline \multirow{2}{*}{$\begin{array}{c}\text { Height } \\
\text { differential }\end{array}$} & \multicolumn{2}{c}{ Flower colour } & & & & & \\
\cline { 2 - 6 } & Red & Pink & Total & Expected & G & df & \\
\hline Zero & 40 & 49 & 89 & 44.5 & 0.911670 & 1 & ns \\
Eight & 56 & 46 & 102 & $51 \cdot 0$ & 0.981969 & 1 & ns \\
Sixteen & 56 & 54 & 110 & $55 \cdot 0$ & 0.036366 & 1 & ns \\
Pooled & 152 & 149 & 301 & $150 \cdot 0$ & 0.029901 & 1 & ns \\
\hline
\end{tabular}


The dual pollination experiment demonstrated that the pink and redflowered variants are cross-compatible and cross-fertile. Dual pollinations with the pink-flowered variant as the female parent yielded 48 per cent hybrids as compared to the expected 50 per cent; such pollinations on the red-flowered variant yielded 46 per cent hybrids (table 5). Although there was a small deficiency of hybrids, parental types and hybrids did not deviate significantly from equality. Accordingly, we propose that the substantial deficiencies of hybrids produced in the experimental populations are due in very large measure if not exclusively to pollinator foraging behaviour.

TABLE 5

Progeny of dual pollinations involving two P. drummondii variants

\begin{tabular}{|c|c|c|c|c|c|}
\hline \multicolumn{6}{|c|}{ Progeny of pink-flowered variants } \\
\hline Parental & Hybrid & Expected & G & df & \\
\hline 47 & 43 & 45 & 0.1778 & 1 & ns \\
\hline \multicolumn{6}{|c|}{ Progeny of red-flowered variants } \\
\hline 56 & 50 & 53 & $0 \cdot 3398$ & 1 & ns \\
\hline \multicolumn{6}{|c|}{ Progeny of both variants } \\
\hline 103 & 93 & 98 & 0.5104 & 2 & ns \\
\hline
\end{tabular}

\section{Discussion}

Positive assortative pollination within a polymorphic population is the population counterpart of flower constancy, i.e., the tendency of single pollinators to restrict their foraging to flowers of a single species although suitable flowers of other species are present. Both assortative pollination and flower constancy are the consequences of pollinator response to differences in flower colour, form, size and fragrance (Grant, 1949; Free, 1970; Levin, 1978a; Waser, 1983). In contrast to floral constancy, assortative pollination has been documented in only a few instances (Kay, 1978, 1982). In addition to providing an additional example of assortative pollination, the present study is the first to document assortment in a red-pink mixture by any class of pollinator, the first to document assortment for stature in a lepidopteran pollinated species, and the first to use progeny tests to describe the cumulative effect of pollen flow.

Pollinators of $P$. drummondii can discriminate among a broad range of flower colour variants (Levin, 1972), and forage assortatively as seen in this study. In plots where two variants had the same stature, the frequency of hybrids was 0.37 vs the expected $0 \cdot 50$. Whereas we have demonstrated a significant departure from random mating, we do not wish to imply that the mating system within a given mixture is invariant. Indeed, the frequency of hybrids probably would have been quite different were the experiment conducted at another plant density or population size because pollinator response to divergent floral signals is dependent upon these variables (Levin, $1978 b$ ). In synthetic populations of $P$. drummondii cultivars, the level of assortment among colour variants is positively correlated with plant density (Watkins and Levin, unpubl.). This relationship also has been observed in bee-pollinated systems (Marden and Waddington, 1981). In natural dimorphic populations of $P$. pilosa, the level of assortment is less in small 
populations than in large ones (Levin, unpubl.). These observations are consistent with the relationship between flower constancy, and population size and density in multispecies assemblages (Levin, 1978b), and indicate the dynamic nature of assortative mating.

In a dense array of plants heterogeneous in status, the average distance between flowers of neighbouring plants is least if plants are similar in stature. Since pollinators forage economically (Heinrich, 1983; Waddington, 1983), we would expect them to pollinate assortatively for stature, the greater the variance in the latter the greater the degree of assortment. Assortative pollination for stature has been observed in the bee-pollinated Lythrum salicaria (Levin and Kerster, 1973) and Brassica oleracea (Faulkner, 1976). The present study is the first to demonstrate that assortment for stature is dependent on the height differential.

Assortative mating in plants probably is much more common than one would judge from the literature. Assortative mating will occur if one group of pollinators prefers one morph while another groups prefers an alternative morph as has been shown in several species (Kay, 1982; Miller, 1981). Assortative mating will also occur in the absence of morph preference if pollinators distinguish between alternate morphs and display some level of flower constancy. This pollination pattern has been observed in Phlox drummondii and in Lantana camara (Dronamraju, 1960) and Antirrhinum (Mather, 1947). Assortative mating also will ensue if alternate morphs were clumped in space even if pollinators did not discriminate between them, provided that pollinator flights were principally between neighbouring plants. This pollination pattern is the norm in most plant populations (Levin and Kerster, 1974; Levin, 1981). The patchy distribution of alternate morphs has been documented in Linanthus parryae (Epling and Dobzhansky, 1942; Epling, Lewis and Ball, 1960), Cirsium palustre (Mogford, 1974), and Leavenworthia crassa (Lloyd, 1969).

It is important to know the extent and magnitude of assortative mating in plant populations, because this mating pattern may promote the maintenance of floral polymorphisms through its effects on the genetic constitution of populations. In addition to increasing the incidence of the recessive phenotype, assortative mating may reduce the influx of neutral or weakly beneficial alleles (Moore, 1979) or increase the genetic load (Lande, 1977). For quantitative characters, assortative mating inflates the total phenotypic variance, but disproportionately inflates the additive genetic variance so that the heritability of the character, and hence the effect of selection is potentially increased (Breese, 1956; Crow and Felsenstein, 1968; Crow and Kimura, 1970). Assortative mating also increases the patchiness of phenotypes in space beyond that achieved by restricted gene flow (Stephen, Turner and Anderson, unpubl.).

Given the potential for assortative mating in plants and its manifold effect, it is clear that this form of non-random mating warrants closer scrutiny. Our preoccupation with inbreeding has diverted attention from this form of non-random mating to the point where it has been ignored.

Acknowledgements. The support of National Science Foundation Grant DEB-8119484 is gratefully acknowledged. We thank Drs Keith Clay and C. Schlichting for their critical readings of the manuscript, and Pat Firey for statistical advice. The project was conducted at the Brackenridge Field Laboratory of the University of Texas, Austin, and we thank J. Crutchfield for his assistance there. The authors are indebted to an anonymous reviewer for suggestions on statistical procedures. 


\section{REFERENCES}

BREESE, E. L. 1956. The genetical consequences of assortative mating. Heredity, 10, 323-343. CLEGG, M. T. 1980. Measuring plant mating systems. BioScience, 30, 814-818.

CROW, J. F. AND FELSENSTEIN, J. 1968. The effect of assortative mating on the genetic composition of a population. Eugen. Quart., 15, 85-97.

CROW, J. F. AND KIMURA. 1970. An Introduction to Population Genetics Theory. Harper and Row, New York.

DRONAMRAJU, K. R. 1960. Selective visits of butterflies to flowers: a possible factor in sympatric speciation. Nature, $86,78$.

EPLING, C. AND DOBZHANSKY, T. 1942. Genetics of natural populations. VI. Microgeographical races in Linanthus parryae. Genetics, 27, 317-332.

EPLING, C., LEWIS, H. AND BALL, F. M. 1960. The breeding group and seed storage: a study in population dynamics. Evolution, 14, 238-255.

FAEGRI, K. AND VAN DER PIJL, L. 1979. The Principles of Pollination Ecology. 3rd edition. Pergamon, New York.

FAULKNER, G. J. 1976. Honeybee behaviour as affected by plant height and general colour in Brussels sprouts. J. Apic. Res., 5, 15-18.

FREE, J. B. 1970. Insect Pollination of Crops. Academic Press, New York.

GALEN, C. AND KEVAN, P. G. 1980. Scent and colour, floral polymorphisms and pollination biology in Polemonium viscosum. Nutt. Amer. Midl. Natur., 104, 281-289.

GRANT, V. 1949. Pollination systems as isolating mechanisms in angiosperms. Evolution, 3, 82-97.

GRANT, V. 1963. The Origin of Adaptations. Columbia Univ. Press, New York.

HARDING, J. 1970. Genetics of Lupinus II. The selective disadvantage of the pink flower colour mutant in Lupinus nanus. Evolution, 24, 120-127.

HEINRICH, B. 1983. Insect foraging energetics, pp. 187-214. In Jones, C. E. and Little, R. J. (eds.), Handbook of Experimental Pollination Biology. Van Nostrand Reinhold, New York.

HESLOP-HARRISON, J. 1958. Ecological variation and ethological isolation, In O. Hedberg (ed.), Systematics of Today. Uppsala, Sweden.

KAY, Q. O. N. 1976. Preferential pollination of yellow-flowered morphs of Raphanus raphanistrum by Pieris and Eristalis ssp. Nature, 261, 230-232.

KAY, Q. O. N. 1982. Intraspecific discrimination by pollinators and its role in evolution, pp. 9-28. In Armstrong, J. A., Powell, J. M. and Richards, A. J. (eds.), Pollination and Evolution. Royal Botanic Gardens, Sydney.

KYHOS, D. W. 1971. Evidence of different adaptations of flower colour variants of Encelia farinosa (Compositae). Madrono, 21, 49-112.

LANDE, R. 1977. The influence of the mating system on the maintenance of genetic variability in polygenic characters. Genetics, $86,485-498$.

LEVIN, D. A. 1972. The adaptedness of corolla colour variants in natural and experimental populations of Phlox drummondii. Amer. Natur., 106, 57-70.

LEVIN, D. A. 1975. Interspecific hybridisation, heterozygosity and gene exchange in Phlox. Evolution, 29, 37-51.

LEVIN, D. A. 1978a. The origin of isolating mechanisms in flowering plants. Evol. Biol., 11, 185-317.

LEVIN, D. A. 1978 b. Pollinator behaviour and the breeding structure of plant populations, pp. 133-150. In Richards, A. J. (ed.), The Pollination of Flowers by Insects. Academic Press, London.

LEVIN, D. A. 1981. Dispersal versus gene flow in plants. Ann. Missouri Bot. Gard., 68, 233-253.

LEVIN, D. A. AND KERSTER, H. W. 1973. Assortative pollination for stature in Lythrum salicaria. Evolution, 27, 144-152.

LEVIN, D. A. AND KERSTER, H. W. 1974. Gene flow in seed plants. Evol. Biol., 7, 139-220.

LLOYD, D. 1969. Petal colour polymorphism in Leavenworthia (Cruciferae). Contri. Gray Herb. Harvard, 198, 6-40.

MARDEN, J. H. AND WADDINGTON, K. D. 1981. Floral choices by honeybees in relation to the relative distances of flowers. Physiol. Entomol., 6, 431-435.

MATHER, K. 1947. Species crosses in Antirrhinum. I. Genetic isolation of the species majus, glutinosum and orontium. Heredity, $1,175-186$.

MILLER, R. 1981. Hawkmoths and the geographic patterns of floral variation in Aquilegia caerulea. Evolution, 35, 763-774.

MOGFORD, D. J. 1974. Flower colour polymorphism in Cirsium palustre. 1. Heredity, 33, 241-256.

MOORE, W. S. 1979. A single-locus mass action model of assortative mating, with comments on the process of speciation. Heredity, 22, 173-186. 
SOKAL, R. R. AND ROHLF, F. J. 1981. Biometry 2nd ed., W. H. Freeman, San Francisco.

STACE, C. A. 1977. The origin of radiate Senecio vulgaris L. Heredity, 39, 383-388.

STACE, H. M. AND FRIPP, Y. J. 1977. Raciation in Epacris impressa. II. Habitat differences and flowering times. Aust. J. Bot., 25, 315-323.

WADDINGTON, K. D. 1983. Foraging behaviour of pollinators, pp. 213-239. In Real, L. (ed.), Pollination Biology. Academic Press, New York.

WALLER, G. D., LOPER, G. M. AND BERDELL, R. L. 1974. Olfactory discrimination by honeybees of terpenes identified from volatiles of alfalfa flowers. J. Apicult. Res., 13, 191-197.

WASER, N. M. 1983. Competition for pollination and flower character differences among sympatric plant species: a review of evidence, pp. 278-293. In Jones, C. E. and Little, R. J. (eds.), Handbook of Experimental Pollination Biology. Scientific and Academic Editions, Van Nostrand, New York.

WASER, N. M. AND PRICE, M. V. 1981. Pollinator choice and stabilising selection for flower colour in Delphinium nelsonii. Evolution, 35, 376-390.

WATSON, P. L. 1969. Evolution in closely adjacent populations. VI. In entomophilous Potentilla erecta, in two contrasting habitats. Heredity, 24, 407-422. 